Trinity University Digital Commons@ Trinity

Modern Languages and Literatures Faculty

Research

Modern Languages and Literatures Department

2016

\title{
The Dark Pastoral: Goethe and Atwood
}

Heather I. Sullivan

TrinityUniversity, hsulliva@trinity.edu

Follow this and additional works at: http://digitalcommons.trinity.edu/mll_faculty

Part of the Modern Languages Commons

\section{Repository Citation}

Sullivan, H. I. (2016). The dark pastoral: Goethe and Atwood. Green Letters, 20, 47-59. doi: 10.1080/14688417.2015.1116403

This Article is brought to you for free and open access by the Modern Languages and Literatures Department at Digital Commons @ Trinity. It has been accepted for inclusion in Modern Languages and Literatures Faculty Research by an authorized administrator of Digital Commons @ Trinity. For more information, please contact jcostanz@trinity.edu. 


\title{
The dark pastoral: Goethe and Atwood
}

\author{
Heather I. Sullivan \\ Modern Langs \& Lits, Trinity University, San Antonio, USA
}

\begin{abstract}
The Anthropocene challenges the humanities to find means of representing and analysing our fossil-fueled practices that have spread industrial particulates over the entire globe, changed the climate, and reshaped landscapes into a "new nature." In this essay, I propose the "dark pastoral" as an analytical trope, examining two framing texts from the Anthropocene: Goethe's landmark 1797 pastoral German epic, Hermann and Dorothea, and Margaret Atwood's 2003 postapocalyptic novel Oryx and Crake, the first installment of her MaddAddam trilogy which ends with a surprisingly pastoral flourish. At the early phases of the Anthropocene (as it is defined by Paul Crutzen, at least), Goethe creates an epic pastoral whose materiality points darkly towards the impending modernity of capitalism. Atwood's, postapocalyptic versions of a damaged yet rejuvenating Earth directly dramatise the Anthropocene's destruction while ending with a "new" pastoral that relies on an almost total obliteration of humanity: these are dark pastoral visions.
\end{abstract}

\section{ARTICLE HISTORY}

Received 1 June 2015

Accepted 2 November 2015

KEYWORDS

Anthropocene; dark ecology; climate change; pastoral; ecocriticism; toxic discourse

Literature and the humanities are challenged to find ways of representing and analysing the physical environment in the "Anthropocene," the newly described geological era that begins with the eighteenth-century Industrial Revolution. In 2000, Nobel Laureate in atmospheric chemistry Paul Crutzen and his colleague Eugene Stoermer coined the term Anthropocene to describe our current situation in which humankind has impacted every part of the Earth's surface and many of the biospheric systems through the spread of industrial particulates over the entire globe, the increased use of fossil fuels and release of carbon dioxide, the upswing in capitalism, and the reshaping of landscapes into a "new nature." We need a means to imagine and understand this vast scale of impact and to represent it so that we can respond to it. In this essay, I propose the "dark pastoral" as such a means of representation, examining two significant framing texts from the Anthropocene: Goethe's landmark 1797 pastoral German epic, Hermann and Dorothea published at the very beginning of the Anthropocene before one could know what the impact of the Industrial Revolution and capitalism together would be, and Margaret Atwood's 2003 postapocalyptic novel Oryx and Crake, the first installment of her MaddAddam trilogy which, by the third novel, ends with a surprisingly pastoral flourish and represents the Anthropocene once it is aware of itself. In other words, the dark pastoral is not so much a description of particular types of texts (a pseudo-pastoral 
genre) as it is a formula for navigating the textual and material contradictions of the Anthropocene. The dark pastoral can describe texts like Goethe's epic that predate many of these changes yet point towards a sense of impending change - both threatening and promising - and that thus try to escape into the green fields, or texts that directly grapple with environmental pollution and the impacts of capitalism like Atwood's.

Both Goethe's and Atwood's stories indulge in similar pastoral-like idealisations of lush nature-scapes with thriving, vibrant, and fecund realms of greenery. In the case of Goethe, these nature-scapes are contained within gated agricultural spaces of the "landed bourgeoisie" (if there could be such a category that emerges forcefully with capitalism, the increased use of fossil fuels, and the Industrial Revolution); with Atwood, they are vigorously spreading in the wake of a worldwide genocide that allows the flourishing of genetically altered animal species and rain-forest effervescence in the now sweltering climate-changed North American east coast. Studying these two very different genres, an epic poem and a novel, with reference to the pastoral is helpful since both borrow the typically pastoral impulse to relegate large-scale cultural changes to the background behind a lush, green backdrop. Goethe's poem, for example, references only from afar the Napoleonic wars threatening to spill over into Germany bringing violence and new forms of economic and political modernity. Atwood weaves together lunch conversations about bacon sandwiches and access to meat in a time of restricted availability with brief asides about the warming world devastated by globalised capitalism and the concomitant massive species extinction that has been described by Elizabeth Kolbert (2014) as the "sixth extinction" event on planet Earth.

So here we call the pastoral into play, dangerously perhaps, not as "genre," but rather as a "formula" for describing the physical world with an emphasis on lush foliage that hides threatening cultural change - but that also fulfills our apparent need for greenscapes and nonhuman life. The pastoral's formulae evoke two very different sentiments: the deeply green ecological ideals still at the core of much ecocriticism and environmentalism, yet also a darkly tainted history of imperialistic power struggles both local and global over land use. The "dark pastoral" spans this seemingly unbridgeable divide and so enacts the Anthropocene's vivid extremes. Its very darkness is meant both as a critique of, on the one hand, naively accepting pastoral impulses and, on the other, of thinking that we can overcome these very urges without confronting and engaging this necessary fantasy, as Leo Marx described it already in his 1964 The Machine in the Garden. The dark pastoral, as strategy and trope, is a doubled movement closer towards and away from green fantasies.

Although the dark pastoral is one among many recently proliferating revisions of the pastoral including Terry Gifford's "post-pastoral" (2014), Greg Garrard's "radical pastoral" (1996), David Farrier's "toxic pastoral" (2014), and the lyrical forms of the "necropastoral,"1 ${ }^{11}$ what differentiates the dark pastoral from all of these is exactly this emphasis on double movements, a bridging of incompatible contrasts that must actually be thought together, at least in the capitalist Anthropocene. ${ }^{2}$ Such double movements are in fact, typical of the long pastoral tradition whose requisite documentation of a seemingly simple, rural nature suggests, albeit in the negative, a contrasting vision of complex urban power and politics. The traditional pastoral, like Goethe's epic, seems to portray a static place of simplicity yet it more precisely enacts a double movement whereby documentation of the countryside inevitably points towards the (ostensibly) 
absent machinations of urban power, politics, and war. In Terry Gifford's terms, this is a "retreat and return," and as such, it belies the notion that pastoral texts portray only an aesthetic green surface.

With the traditional pastoral, I refer to the second and third of Gifford's three categories described in Pastoral. He first defines the original literary form long associated with poetry and drama; second, the general textual references to rural landscapes and the countryside; and third, the derogatory use of the term to describe an overly idealised vision of such places that overlooks their material and economic practicalities (Gifford 2010). The pastoral can provide, as Gifford and Lawrence Buell (1995) note, an alternative space in contrast to the urban technological practices of modern and postmodern fossil-fueled capitalism. Yet, on the other hand, the more idyllic qualities of the traditional pastorals often conceal the power structures that provide the very possibility of idealised landscapes for their lucky inhabitants. The pastoral potentially connotes colonial exploitation and genocide as well as the exploitation of natural resources both locally and globally with the corresponding extremes of social injustices. As Ken Hiltner writes of the Renaissance pastoral imagining distant green places: "such literature not only encouraged appreciation of environments imagined as pristine, but also the mass exploitation of these newly emerging environs. Consequently, these colonised countrysides appeared not as valuable and worth saving, but as ripe for exploitation" (Hiltner 2011, 14). While the traditional pastoral texts conceal power behind nostalgic views of an imagined utopian past - thus either offering an actual alternative or subtly embodying the very power structures it appears to critique - the dark pastoral trope reveals these double movements themselves.

Additionally, the dark pastoral is a means of thinking landscapes in terms of material ecocriticism's emphasis on flows and nonhuman agency together with human agency. A dark pastoral frame notes how the Anthropocene means that we can no longer think of ecological and economic cycles independently: the water; carbon; nitrogen; weather; and economic cycles of production, exchange, and waste are interconnected. Such an integration of physical, elemental, cycles, and human cycles since the Industrial Revolution is, in fact, the very definition of the Anthropocene according to the scientists, Crutzen and Stoermer (2000), historian Dipesh Chakrabarty (2008), and author of Anthropocene Fictions, Adam Trexler (2015), among others. Hence we need textual modes that depict an integration of human industrial cycles with ecological cycles, and thus of human and natural history together. The additional need for modes engaging double movements validates continued use of the pastoral trope in ecocriticism, precisely because (not despite the fact that) it performs duplicitous thought. ${ }^{3}$ This essay is an exploratory effort mapping the possibilities of the dark pastoral's attention to double moves and conjoined material cycles for the Anthropocene.

Goethe's idyllic verse in Hermann and Dorothea rather ironically documents how the wealthy middle class accommodates refugees fleeing the Napoleonic wars, at least to the extent that they do not jeopardise their own comfort. The epic is a myopic love story between the homebody Hermann and the valiant refugee Dorothea; its slow move into the marriage plot almost entirely overwrites the standard epic fare of major political and military upheavals and the associated devastation to people and lands. We read instead lengthy descriptions of the surface green, that is, the lush gardens, golden fields of grain, and huge shady trees. Hermann and Dorothea carefully documents middle-class material 
circumstances and the fear of their disruption. This materiality is presented as long lists of things and pieces of property in the poem. Instead of epic ancestors and battles, elaborate feasts, and political entanglements, Goethe portrays the refugees' wagons loaded up with blankets, mirrors, old clothes, and limited food supplies. As shocking as the human suffering is, the narrator focuses primarily on the stuff that they transport and the goods that they need to survive as an expression of their woes. Change is documented as a (darkly tainted) upswing in the flow of things. Atwood's Oryx and Crake, in contrast, focuses on the wreckage of human beings and human objects alike in her postapocalyptic situation. The novel opens as Jimmy the Snowman begins his "last man" narrative by reading his broken watch and realising that the end of this particular object signifies - with horrifying implications - the end of all modern culture demarcated by its time-keeping quest. Nevertheless, the trilogy closes with MaddAddam's exploration of a new pastoral world in which the (genetically enhanced) pigoons create a peaceful coexistence with the now mixed (posthuman) "Craker-human" species, portraying hope for a renewed, balanced ecological existence. Atwood's trajectory is from total devastation to a new world troublingly "rescued" by the elimination of the vast majority of humanity (this ecological solution of mass genocide is a disturbingly common strategy for much of postapocalyptic, eco-science fiction). In other words, Atwood and Goethe exemplify two different directions of the dark pastoral's doubled movements: Atwood enacts nostalgia (looking back) in a declensionist narrative (that looks forward), and Goethe looks forward towards impending change by writing in a genre (the epic with heavily traditional pastoral overtones) that points backward.

Gifford contextualises such double movements explicitly in terms of the pastoral's tensions and inherent contradictions that render it so versatile:

So the pastoral can be a mode of political critique of present society, or it can be a dramatic form of unresolved dialogue about the tensions in that society, or it can be a retreat from politics into an apparently aesthetic landscape that is devoid of conflict and tension. It is this very versatility of the pastoral to both contain and appear to evade tensions and contradictions - between country and city, art and nature, the human and the non-human, our social and our inner selves, our masculine and feminine selves - that made the form so durable and so fascinating. $(2010,11)$

Consequently, the pastoral contains within it - always already - the seeds of the postmodern instability. Gifford writes:

But significantly for latter-day environmental literary criticism, a postmodern usage of pastoral is possible precisely because of the instabilities, tensions, and paradoxes embedded from the beginning in the simultaneous realism and artifice of the discourses of Arcadia real place and cultural construct. $(2014,19)$

This is the unstable ground for the dark pastoral, though the move into darkness still requires a few additional steps.

David Farrier provides one of these steps with his study of the toxic pastoral in comic form, thereby expanding Gifford's earnest post-pastoral efforts at accommodating ecofeminism and queer theory while maintaining an association with awe and thus the sublime. In Farrier's "toxic pastoral," the sublime is degraded and made comedic,

presenting an engagement with and celebration of the ambivalence in human interactions with the more-than-human world. Toxic pastoral foregrounds the 'impure' and symbiotic 
rather than the 'pure', separated (albeit mutually-reinforcing) civic and rural spaces of conventional pastoral. $(2014,4)$

The toxic pastoral derives from Buell's famous "toxic discourse," thus insisting upon the "interdependence of ecocentric and anthropocentric values," yet Farrier abandons Buell's "self-conscious localism" and instead "evokes toxicity as a trope" $(2014,4)$. The comedic toxic opens the pastoral to irony and the impure.

Timothy Morton's notion of "dark ecology" offers another step towards the dark pastoral in the Anthropocene. It describes a participatory situatedness within the "mesh," and studies "all kinds of art forms as ecological, not just ones that are about lions and mountains, not just journal writing and sublimity" (Morton 2010, 17). Dark ecology, in Morton's words, is ironic, implicated, and complicit. Its form is

that of noir film. The noir narrator begins investigating a supposedly external situation, from a supposedly neutral point of view, only to discover that she or he is implicated in it. The point of view of the narrator herself becomes stained with desire. There is no metaposition from which we can make ecological pronouncements. (Morton 2010, 17)

Above all, Morton declares dark ecology to be already here, as a means of coping with a catastrophe that has already occurred. Dark ecology offers a perspective from within the ongoing environmental crisis, as does the dark pastoral, but the latter maintains a commitment to literature and the apparent impossibility of escaping our tendency towards pastoral dreaming. Nor would we actually want to eradicate entirely these dreams of sheep, electric, or otherwise.

In Hermann and Dorothea, we see the attraction: Goethe indulges the reader with magnificent fields and gardens leaning far closer to pastoral paradise than the epic battlegrounds one might expect considering its proclaimed genre. The only battleground in the epic poem is that of the heart. It opens as Hermann's hometown is emptied during the Napoleonic Wars when the townspeople have gone to gawk or share goods with the refugees fleeing the French, who are safely regulated offstage in the distance. The refugees pour into the local area, but also remain comfortably far from Hermann's home. Hermann is delayed in bringing various cast-off clothes and food to the fleeing folk because his mother cannot decide which wine and what old bathrobes should be donated. T.J. Holmes sees Goethe's epic as an ironic tale of the "declining idyll," in which Hermann and Dorothea must soon face the radical changes of economic growth brought with impending modernity rather than war. Goethe was "perfectly aware of the untenable position of a static, parochial order in face of the immense new economic forces of the time" (Holmes 1987, 117). With the use of the dark pastoral's attention to materiality, the celebration of goods and things that are possessed and/or redistributed along with people and land appears the most dramatic aspect of the epic, and Holmes's "declining idyll" is contextualised at the cusp of the Anthropocene. In the opening scene, Hermann's mother gathers things to donate, explaining:

I am not always inclined to dispose of old linen.

Many the time I might use it, and money never can buy it

Just at the moment of need. But today I had no misgivings:

Excellent bedclothes and shirts I cheerfully, willingly offered,

When I heard of children and old folks who have no more clothing. [...]

Even your favorite housecoat I took, with the Indian flowers, 
Made of the very best cotton, and lined with quality flannel.

You cannot wear it again: it is thin and gone out of fashion. (Goethe 1976, 5)

By the time she finally hands these items to Hermann and he sets off to seek the refugees, the other villagers are already returning to their homes. The returning pastor tells of the dust and exhausted people, "mile after mile the procession extended over the landscape" (Goethe 1976, 11). In all the crowds and dust, the most salient features are the refugees' assembled possessions:

Sad was the sight; all their possessions scattered about them, Things that belong in a house, secure in peaceful abundance ... What a pity to see so many things in disorder! Loaded on wagons and barrows, rescued in haste from the houses; Woolen blankets share with a sieve the top of the bureau; Quilts lie stuffed in a trough, and a tablecloth clovers the mirror. (11-13)

Hermann finally arrives in time to see the tail end of the procession. There he meets the beautiful and noble Dorothea. Her self-sacrificing generosity inspires his trust, so much so that gives to her all of the goods he has brought and asks her to distribute them as she sees fit. Their first conversation relates to the distribution of goods.

Excellent maiden, my mother has laden my carriage not only With the linen for clothing the naked, but also he added Food to nourish the body, and various drinks for refreshment. There in the box of the wagon I have them all ready, in plenty. I am however inclined at this moment to put you in charge of Everything; thus I fulfill my commission most wisely and well for You will distribute it fairly, while I would be acting at random. (27)

Their epic romance begins with lists of things and material possessions. This soon leads to respect and love; and so the young Hermann desires to ask for her hand in marriage. Their pastoral romance emerges from the exchange of middle-class goods.

Unfortunately, Hermann is despondent when his father rejects the idea of marrying Dorothea. And so he leaves her with the refugees and retreats deep in the lush gardens of his wealthy middle-class estate, weeping. His mother seeks him out and eventually is able to convince him not to run off and be a soldier but instead to stay and talk with Dorothea. Here we see why the epic is so often described as an "idyll": his mother's walk is an opportunity for Goethe to elaborate on their lush lands (Holmes 1987; Ryder and Bennett 1975). She traverses the "long double courtyard," passes the stables and hay barn, "entered the garden, which stretched right out to the walls of the city"; goes through the arbor, exits the gate and climbs past the moat up into their vineyard lush with grapes of many varieties, tops the hill and goes on to the fields of grain (Goethe 1976, 53).

And so she presently entered the grainfield,

Which in its spacious expanse extended over the hillside.

Still all the ground was her own, over which she continued to wander.

Pleased with the crops she had sown, with the grain ears splendidly waving,

Stirring in golden magnificence over the face of the grainfield.

Through the fields then she passed, on the footpath which served as a border, 
Aiming straight for the peartree, the large one that stood on the hill and Marked the boundary and end of the fields which belonged to the family. Nobody knew who had planted it. Far and wide in the landscape People could see it; the fruit of the tree was also quite famous. Under its branches the mowers, resting, would eat in the noontime; Herdsmen were much in the habit of tending their flocks in its shadow.

It is under the über-pastoral pear tree, which shades the shepherds and mowers alike, where his mother finds Hermann, alone, and weeping. He declares a need to protect their lands from the French by becoming a soldier, which is his cover story for the discomfort at being interested in Dorothea but unable to propose to her. He fears approaching her and disappointing his father, who wishes him to marry one of the many spoiled and "overly educated" daughters of the richest man in the town. These challenges are eventually overcome with the help of his mother, the pastor, and the ever-heroic Dorothea.

In Goethe's tale, Hermann's lands enact the pastoral peace in the odd form of long lists of material goods and agricultural forms. The epic contains the standard doublemovement of relegating the political turmoil, in this case war, to the background. Dominating the storyline are love and rural landscapes, whereas the urban battles of Paris and brought in only in the figure of Dorothea who will be tamed by a marriage contract, thereby leaving behind her heroic past. She needs taming; after all, she was previously engaged to a revolutionary who was killed in the battles. We are told that she dramatically rescued with a sword several other young women in a harrowing encounter with marauding soldiers who rampaged her home. Goethe's pastoral does the double movement of overwriting the violence with lovely scenery - we hear of it from afar, after the fact, while comfortably at home with the wealthy middle-class Germans amidst their green fields. The epic ends when Hermann, finally, proposes to Dorothea and declares that all this land around him is "his." Note the possessives:

You are mine: now that which is mine is mine more than ever.

I will not keep it in sorrow nor mar its enjoyment by worry.

I will use my courage and strength. Should enemies threaten

Now or in the future, get my equipment and hand me my weapons.

(167, emphasis mine)

Reading Goethe's idyllic Hermann and Dorothea through the dark pastoral, we note the concentration on economic commodities with long lists of things and possessions being moved, exchanged, and celebrated. Such lists are typical of epic celebrations, of course; one need only think of the lists of exquisite clothes, weapons, and meals in the Nibelungenlied or the lliad. Unlike the things in those epics that are possessed only by the aristocracy or the divine, who dole them out in elaborate ceremonies, the possessions of Hermann and Dorothea are owned and distributed by the middle class to refugees after much deliberation. The goods are carefully monitored, and as much attention is paid to the disarray of the refugees' transported items as the raw human suffering. Goethe was quite skeptical regarding specific economic developments of the late eighteenth and early nineteenth century, including the banks' use of paper money (Gray 2008), and, as he quips in Faust, he was critical of the "holy trinity" of trade, war, 
and piracy that Mephistopheles engages. Goethe thereby critically charts the Anthropocene's ever more profitable spread of capitalism. But his view of nature remains bright green and pastorally tinged even if occasionally stormy. Although the traditional pastoral is known for its nostalgia looking backward towards an ever-receding lost "golden age," Goethe's Hermann and Dorothea changes this trajectory into an ironic reversal with a darkly skeptical glance towards the future, a future of increased traffic and commodities and the questionable power of the middle class. And so we enter the Anthropocene, an era that embodies, in literary terms, the dark pastoral.

Moving into the later Anthropocene necessitates a darkening even while upholding, paradoxically, the pastoral dreams of places benefiting from urban power but concealing it. In these terms, Buell's "toxic discourse" is also helpful for mapping the dark pastoral. Buell replaces the idealised "ecological holism" with a nature more apt for the Anthropocene, a nature that is

not a holistic spiritual or biotic economy but a network or networks within which, on the one hand, humans are biotically imbricated (like it or not), and within which, on the other, hand, first nature has been greatly modified (like it or not) by techne. (Buell 2001, 45, emphasis in original)

While the dark pastoral is informed by toxic discourse, it is also inspired by Ursula Heise's concern that Buell's toxic pastoral still remains too idealistic. Heise states she is

less confident than Buell that the longing for a return to precisely such a naturally balanced world does not inform many of these descriptions of exploited, deformed, and polluted landscapes and bodies as an imaginary countermodel. [...] [These] seem to spell out a pastoral countermodel to the toxic world. $(2008,140)$

Yet the continued desire (and need, even) for countermodels is a reason to utilise the dark pastoral as a trope embodying the paradoxes of the Anthropocene: the pastoral dream remains deeply embedded in environmentalism and it continues to be a driving force in ecocriticism. There is likely no final escape from these idyllic hopes - after all, our need for green-scapes goes deeper than the Anthropocene.

Heise also points out that such pastoral pleasures - when used as countermodels to the new, toxic nature - rather inevitably lead to shattered illusions and thus apocalyptic narratives. And indeed, the postapocalypse is the flipside of idyllic green dreams, at least when narrated in the Anthropocene when there is no place outside of the industrially impacted ecosystems on Earth. Hence we perhaps inevitably move from Goethe's darkly pastoral idyll into an expression of its flip side, Atwood's postapocalyptic world. As a trope for navigating the Anthropocene's paradoxes, the dark pastoral can subtly reveal early phases of this era or dramatically expose the toxic "new nature" while celebrating unstoppably vigorous flora or nonhuman fauna.

In Atwood's Oryx and Crake, the first book of the trilogy, we enter a postapocalypse. It initially appears that only Snowman has survived to tell his "last man" postapocalyptic narrative as he guides the posthuman, eco-friendly Crakers to life outside of the lab where they were created. In this first of the novel's two timelines, Snowman returns to that lab, "Paradice," in order to gather supplies and to confront his past and the corpses of Crake and Oryx. Atwood plays with the last-man genre here, since we later discover that there are, in fact, other survivors; but for most of the novel, Snowman must 
experience the end of civilisation on his own, slowly starving in a polluted but very quickly regreening world filled with genetically hybrid animals gone feral. While he drinks the last bottles of alcohol, ponders the antics of the beautiful vegan Crakers, and sleeps through sweltering thunderstorms in trees to avoid being eaten, Snowman recalls his youth as Jimmy. This second story line appears in a series of recollections tracing Jimmy's path and his friendship with Crake (Glenn) while, in ironically understated yet devastating asides, mentioning the decay of the world as we are now experiencing it. This includes climate change and the absurd yet not inaccurate exploration of what the Internet offers: pornography, snuff films, and game playing. During their surfing, Jimmy and Crake spot the beautiful "Oryx" in a child porn film. Eventually, Crake finds her and saves her from the sex industry, employing her as guide for the Crakers at his lab while he plots the demise of humanity. After their deaths, Jimmy lives to tell their story. Like Goethe's Hermann and Dorothea, Oryx and Crake is a tale of two young lovers in a dangerously changing world who are swept along in tides both destabilising and evoking pastoral expectations.

Atwood stages these tides as virtually un-documentable instances of global climate change, pollution, and lack of environmental justice by listing disastrous changes as asides during mundane conversations of adolescent worries and meal choices. Like Goethe, her darkly pastoral text produces long lists, hers exemplifying what Rob Nixon describes as "slow violence," or the long-term impact of environmental devastation overlooked by the media given that air, water, and soil pollution; species extinction; and asthma in huge numbers of urban children lack the dramatic spectacle of, say, the 2010 "Deepwater Horizon" explosion and oil spill into the Gulf of Mexico. Nixon provides this definition:

By slow violence, I mean a violence that occurs gradually and out of sight, a violence of delayed destruction that is dispersed across time and space, an attritional violence that is an event or action that is typically not viewed as violence at all. Violence is customarily conceived as an event or action that is immediate in time, explosive and spectacular in space, and as erupting into instant sensational visibility. We need, I believe, to engage a different kind of violence, a violence that is neither spectacular nor instantaneous, but rather incremental and accretive [...]. In so doing, we also need to engage the representational, narrative, and strategic challenges posed by the relative invisibility of slow violence. $(2011,2)$

Nixon's concept of slow violence, like the dark pastoral, makes visible the Anthropocene's simultaneous awareness and erasure of catastrophic changes, the normalising of disasters.

Atwood's lists map the very problem of slow violence: it cannot compete with lunch. Jimmy, for example, recalls having stressful lunches with his father in his youth, worrying whether the large quantities of pork served at the laboratory canteen were taken from the genetically altered pigs with human DNA, called "pigoons." Since access to meat was limited, the highly intelligent pigoons were surely the source of the protein-rich lunches. The managers denied it, though:

Still, as time went on and the coastal aquifers turned salty and the northern permafrost melted and the vast tundra bubbled with methane, and the drought in the midcontinental plains regions went on and on, and the Asian steppes turned to sand dunes, and meat became harder to come by, some people had their doubts. Within Organlnc Farms itself it 
was noticeable how often back bacon and ham sandwiches and pork pies turned up on the staff café menu (Atwood 2003, 24).

In another instance, Jimmy, the poor humanities student, visits Glenn/Crake at the exorbitantly wealthy, resort-like science institute, "Watson and Crick." While Crake, in effect, shares his future plans for genocide during this visit, Jimmy simply overhears the message. He fails to notice the possible consequences of what Crake is saying, distracted as he is by the delight of real popcorn with real butter and cold beer - all rare treats. Jimmy might equally well understand but not want to face the implications; either way, he is us and we are Jimmy, and it's lunchtime. Here is Crake telling us about his idea for destroying the entire human population:

"Let's suppose for the sake of argument," said Crake one evening, "that civilization as we know it gets destroyed. Want some popcorn?"

"Is that real butter?" said Jimmy.

"Nothing but the best at Watson-Crick," said Crake. "Once it's flattened, it could never be rebuilt."

"Because why? Got any salt?"

"Because all the available surface metals have already been mined," said Crake. "Without which, no iron age, no bronze age, no age of steel, and all the rest of it. There's metals farther down, but the advanced technology we need for extracting those would have been obliterated."

"It could be put back together," said Jimmy, chewing. It was so long since he'd tasted popcorn this good. "They'd still have the instructions."

"Actually not," said Crake. It's not like the wheel, it's too complex now. Suppose the instructions survived, suppose there were any people left with the knowledge to read them. Those people would be few and far between, and they wouldn't have the tools. Remember, no electricity. Then once those people died, that would be it. They'd have no apprentices, they'd have no successors. Want a beer?"

"Is it cold?"

"All it takes," said Crake, "is the elimination of one generation. One generation of anything. Beetles, trees, microbes, scientists, speakers of French, whatever. Break the link in time between one generation and the next, and it's game over forever."

"Speaking of games," said Jimmy," it's your move" (Atwood 2003, 223).

Unfortunately, Crake's "move" is to carry out this genocide as planned, thereby making slow violence "fast" and brutally eradicating humanity; this act also alleviates the ecological problems of an Earth overrun by human activities. The dark pastoral provides a means of tracing how slow violence is relegated to invisibility, overlooked in the face of good popcorn and lovely trees or left in the distant urban zone.

If Goethe offers an excellent model for the dark pastoral's convoluted strategies and double movements albeit with a heavy dose of ironic green holism, Atwood's initial irony shifts into a seriously pastoral vision at the end of the trilogy. The sudden drop in human population renews the Earth. The remaining people are dedicated to gardening, made more eco-friendly by breeding with the Crakers, and living in peace with the pigoons thanks to the treaty in which they agree not to eat each other. Hannes Bergthaller describes this kind of improbable, pastoral vision as a "fairytale-like ending" to The Year of the Flood, the second book in the trilogy. It is a form expressing the "foundational assumption of ecocriticism - that the roots of the ecological crisis are to be found in a failure of the imagination" (Bergthaller 2010, 741). Atwood's solution, according to Bergthaller, is a revised humanism emphasising "self-domestication" (741). The final installment in the trilogy, MaddAddam, ends with the bees flourishing in the 
growing gardens surrounded by the "new nature," all of which is documented in the fresh new texts being written by hand. This is an idyllic pastoral with inter-species harmony:

Toby said that now we would be safe from the bad ones. And the Pig Ones said their babies were now safe too. And they said also that even though the Battle was over now, they would keep the pact they made with Toby, and with Zeb, and they would not hunt and eat any of the two-skinned ones, and they would also not dig up their garden any more. Or eat the honey of the bees (Atwood 2013, 370).

Atwood's trilogy ends peacefully but in a postapocalyptic dark pastoral scenario that emerges after mass genocide across the planet. As a trope, the dark pastoral reveals this kind forward-moving development into a new nature that is also a retreat into a new pastoral (a double movement), complete with bees and the humanist hope for new texts.

Danette DiMarco reads the trilogy's back and forth as a "return to Paradice," a journey back in time that Snowman must undertake to find Jimmy again and overcome the world-shaping "homo faber" in favor of a non-instrumentalising approach to the nonhuman (DiMarco 2005). This "retreat and return" of the pastoral moves us into the posthuman and postapocalyptic possibilities of the dark pastoral. Similarly, Goethe's shift of the pastoral into a bourgeois idyll laden with possessions and modern economics functions as another form of doubling: a retreat that projects into the future. At the early phases of the Anthropocene (as it is defined by Crutzen, at least), Goethe's pastoral ironically materialises impending modernity idyllically, paving the way for later, Atwoodian, postapocalyptic versions of a damaged yet rejuvenating Earth whose basis is hybridity and harmony with the pigoons.

The dark pastoral provides ecocriticism with specific representational frames that make sense of the Anthropocene's paradoxes by refusing to separate our green dreams from the material manifestations of the new toxic nature. It does this with various doubled concealments and movements: we revel in (dwindling) lush landscapes while traveling the globe and seeking ever "better" energy practices; we race towards ever faster resource extraction and energy use, while the slow violence of pollution, massive extinction rates, melting ice caps, wild storms, and the warming climate all fade away in the face of lunch choices. In the Anthropocene, the mesh has a darkly pastoral flavor.

\section{Notes}

1. The "necropastoral" is a recent poetic category combining "nature" poems with pollution and the frame of the Anthropocene. As Joeyelle McSweeney states: "With my snout up against the fact of the Anthropocene, with my bill snared in fishing line and the blood pooling in my industrially overdeveloped chest and my meager thighs locked and a bolt in my bovine brain, I find myself reeling through an Anthropocenic zone I call the Necropastoral. I first wrote about the Necropastoral in January of 2011. The Necropastoral is a political-aesthetic zone in which the fact of mankind's depredations cannot be separated from an experience of "nature" which is poisoned, mutated, aberrant, spectacular, full of ill effects and affects. The Necropastoral is a nonrational zone, anachronistic, it often looks backwards and does not subscribe to Cartesian coordinates or Enlightenment notions of rationality and linearity, cause and effect. It does not subscribe to humanism but is interested in non-human modalities, like those of bugs, viruses, 
weeds and mold." Described online: http://www.poetryfoundation.org/harriet/2014/04/what-isthe-necropastoral/; accessed 15 July 2014.

2. For brevity, I speak here of the capitalist Anthropocene, though it is certainly larger and could relate to other economic systems as well. Capitalism is the system towards which Goethe is pointing, both with the general hope for a gradual move out of the feudalistic aristocracy in which he was still living and with concern regarding the rapid and problematic changes, and it is very specifically the system that Atwood critiques in her trilogy.

3. I make this claim building on Hiltner's work yet fully aware of the critiques by Greg Garrard and Dana Phillips, who question the "simplicity" of the pastoral's ecologies and its knotty past (Garrard 2012; Phillips 2003).

\section{Disclosure statement}

No potential conflict of interest was reported by the author.

\section{Notes on contributor}

Heather I. Sullivan is Professor of German and Comparative Literature at Trinity University in San Antonio, TX, where she also teaches the Environmental Humanities. Sullivan has published widely in the US and in Europe on ecocriticism, material ecocriticism, the "dark pastoral," Goethe's science and literature, the German romantics, and eco-science fiction. She guest coedited a volume of ecocritical essays with Caroline Schaumann on "Dirty Nature" in Colloquia Germanica 44.2 (2012), published 2014; guest coedited with Dana Phillips ISLE's 2012 special volume on Material Ecocriticism, and guest coedited with Bernhard Malkmus a volume for the New German Critique on "The Challenge of Ecology to the Humanities: Post-Humanism or New Humanism" (forthcoming 2016). She is author of The Intercontextuality of Self and Nature in Ludwig Tieck's Early Works (1997) and is currently coediting a volume with Caroline Schaumann on German Ecocriticism for Palgrave.

\section{References}

Atwood, M. 2003. Oryx and Crake. New York: Doubleday.

Atwood, M. 2013. MaddAddam. New York: Knopf Doubleday.

Bergthaller, H. 2010. "Housebreaking the Human Animal: Humanism and the Problem of Sustainability in Margaret Atwood's Oryx and Crake and The Year of the Flood." English Studies 91 (7): 728-743. doi:10.1080/0013838X.2010.518042.

Buell, L. 1995. The Environmental Imagination: Thoreau, Nature Writing, and the Formation of American Culture. Cambridge: Belknap of Harvard University Press.

Buell, L. 2001. Writing for an Endangered World: Literature, Culture, and Environment in the U.S. and Beyond. Cambridge: Belknap of Harvard University Press.

Chakrabarty, D. 2008. "The Climate of History: Four Theses." Critical Inquiry 35: 197-222. doi:10.1086/596640.

Crutzen, P. J., and E. F. Stoermer. 2000. "The Anthropocene." Global Change Newsletter 41: 17-18.

DiMarco, D. 2005. "Paradice Lost, Paradise Regained: Homo Faber and the makings of a New Beginning in Oryx and Crake." Papers on Language and Literature 41 (2): 170-195.

Farrier, D. 2014. "Toxic Pastoral: Comic Failure and Ironic Nostalgia in Contemporary British Environmental Theatre." Journal of Ecocriticism 6 (2): 1-15.

Garrard, G. 1996. "Radical Pastoral?" Studies in Romanticism 35 (3): 449-465. doi:10.2307/25601 184.

Garrard, G. 2012. Ecocriticism. London: Routledge.

Gifford, T. 2010. Pastoral. London: Routledge. 
Gifford, T. 2014. "Pastoral, Anti-Pastoral, and Post-Pastoral." Chap 1 in The Cambridge Companion to Literature and the Environment, edited by L. Westling, 17-30. New York: Cambridge University Press.

Goethe, J. W. V. 1976. (originally 1797). Hermann and Dorothea. Translated by Daniel Coogan. New York: Frederick Ungar.

Gray, R. T. 2008. Money Matters: Economics and the German Cultural Imagination, 1770-1850. Seattle: University of Washington Press.

Heise, U. 2008. Sense of Place and Sense of Planet: The Environmental Imagination of the Global. New York: Oxford University Press.

Hiltner, K. 2011. What Else is Pastoral?: Renaissance Literature and the Environment. Ithaca, NY: Cornell University Press.

Holmes, T. M. 1987. “Goethe's 'Hermann Und Dorothea': The Dissolution of the Embattled Idyll.” The Modern Language Review 82 (1): 109-118. doi:10.2307/3729916.

Kolbert, E. 2014. The Sixth Extinction: An Unnatural History. New York: Henry Holt.

Marx, L. 1964. The Machine in the Garden: Technology and the Pastoral Ideal. New York: Oxford University Press.

Morton, T. 2010. The Ecological Thought. Cambridge, MA: Harvard University Press.

Nixon, R. 2011. Slow Violence and the Environmentalism of the Poor. Cambridge, MA: Harvard University Press.

Phillips, D. 2003. The Truth of Ecology: Nature, Culture, and Literature in America. New York: Oxford University Press.

Ryder, F. G., and B. Bennett. 1975. "The Irony of Goethe's Hermann und Dorothea: Its Form and Function." PMLA 90 (3): 433-446. doi:10.2307/461630.

Trexler, A. 2015. Anthropocene Fictions: The Novel in a Time of Climate Change. Charlottesville: University of Virginia Press. 